\title{
Degree of Adaptation Strategies by the Livestock Dependents of Drought Prone Districts of Bihar, India
}

\author{
Randhir Kumar Goswami*, Sanjit Maiti, Sanchita Garai, S. K. Jha, \\ M. Bhakat, B. S. Chandel and K. S. Kadian \\ ICAR-National Dairy Research Institute, (Indian Council of Agricultural Research), \\ Karnal - 132001, Haryana, India \\ *Corresponding author
}

A B S T R A C T

\begin{tabular}{l} 
K e y w o r d s \\
$\begin{array}{l}\text { Climate, Drought, } \\
\text { Adaptation strategy, } \\
\text { Livestock } \\
\text { dependents, DA I }\end{array}$ \\
Article Info \\
\hline $\begin{array}{l}\text { Accepted: } \\
\text { 05 February } 2020 \\
\text { Available Online: } \\
\text { 10 March } 2020\end{array}$ \\
\hline
\end{tabular}

Water scarcity and drought are recurrent phenomena in Bihar. The present study was designed to identify and assess the adaptation strategy adopted by the livestock dependents to reduce the impact of drought on their livestock rearing and livelihood security. Adaptation strategies followed by the livestock dependents has recently become a subject of increasing importance in climate change research with an objective to reduce the vulnerability of climate sensitive people. Primary data collected by developing interview schedule with 240 households, which used to get various aspects of drought and drought adaptation strategies. The study accomplished with the help of Drought adaptation Index (DAI). The study found that 49 adaptation strategies were adopted by the livestock dependents which were further distributed into seven broad categories. Most significant adaptation strategies were feeding of extra crop residues, providing minerals supplementation and feed additives instead of green fodder, Storage of wheat straw/paddy straw and crop residues. The study also established that adoption of adaptation strategy was increased significantly with the increase in degree of drought proneness and herd size was the most significant contributor to the higher level of adoption of adaptation strategy.

\section{Introduction}

Drought may be defined as an extended period that is a season, a year or more of deficient rainfall relative to the statistical multi-year average for a region. Any area is declared to be drought prone if that area receives 20.00 percent rainfall during the year examined (IMD, Pune). In 2009, along with many other states, Bihar faced severe drought in which 26 out of 38 districts. Bihar is facing its third drought in 2013 within a span of 4 years and it had been declared 33 out of 38 districts as drought affected. The total estimated crop damage was 12, 58,974 hectares for paddy transplanted and 2, 
22,579.5 hectares for maize totaling to 14 , 81,554 hectares. The estimated loss of production of rice due to the deficient monsoon in these 33 drought affected districts was 36, 18,230 MT. The estimated loss of production of maize was 5, 08,083 MT in 2013 (Department of disaster management, Bihar, 2014). Adaptation can be defined as the adjustment in natural or human system in response to actual or expected climatic stimuli or their effects, which moderates harm or exploits beneficial opportunities (Smit et al., 2000; Smit and Wandel, 2006).

Adaptation has also come to be considered an important response option worthy of research and assessment, not simply in order to guide the selection of the best mitigation policies, but rather to reduce the vulnerability of groups of people to the impacts of climate change, and hence minimize the costs associated with the inevitable (Kane and Shogren, 2000; Pielke, 1998; Smit and Pilifosova, 2001). Traditional practices and power structures may increase a society's adaptive capacity; they may stand in the way of people making more permanent adjustments in response to the occurrence, or threat, of longer-term environmental change (Adger, 1999, 2000; Patt and Gwata, 2002; Ribot, 2002; Ribot et al., 1996).

\section{Materials and Methods}

This study was done in Bihar, the state Bihar had been selected purposively keeping in view the recent droughts. To know the degree of drought proneness, daily rainfall data for 30 years (1984-2013) of different coordinates of Bihar was collected from India Meteorological Department (IMD), and based on this data the number of years of drought faced by each district of Bihar was calculated. Further, based on number of drought years, all 38 districts of Bihar were categorized into three strata i.e. non-drought prone, moderately drought prone and severely drought prone. It was found that there were 17 districts in non-drought prone category, 13 were in moderately drought prone category and remaining 8 were in severely drought prone category. From each category, one district was selected randomly. Thus, Gaya district selected from non-drought prone category, Samastipur district from moderately drought prone category and Bhagalpur district from severely drought prone category. From each district, two blocks were selected randomly and from each selected block two villages were selected randomly. From each village number of livestock dependents were quantified and from each quantified number of livestock dependents, twenty (20) respondents selected randomly. Thus, total sample size for the present study was 240 .

\section{Operationalization and measurement of degree of adaptation}

Adaptation strategy was referred to adjustment in ecological, social or economic systems in response to actual or expected impacts due to drought. Adaptation strategy was operationalised as the measures adopted and/or followed by the livestock dependents to cope up with the adverse impact of drought on livestock rearing and/or their livelihood for sustainable livestock productivity and/or sustainable livelihood security.

A list of adaptation strategies was prepared with the help review of literature, pilot study and expert consultation. Livestock dependents were requested to put their response on a three point continuum viz. continued the adoption, discontinued the adoption and never followed/adopted. All the identified adaptation strategies were used for final index development for all the studied districts. Therefore, in order to quantify the adaptation strategies and the differential level of adoption, a "Drought Adaptation Index" was 
developed underlying the principle of Maiti et al., (2014a) by using the following formula:

Drought Adaptation Index $(D A I)=\frac{\text { Obtained Score }}{\text { Maximum Obtainable Score }}$

Adaptation strategies with higher percentage indicated more cope up capacity comparatively to the adaptation strategies with lower percentage.

\section{Results and Discussion}

Total 49 adaptation strategies were adopted by the livestock dependents of drought prone districts of Bihar, India. All these 49 adaptation strategies were distributed into seven main headings as follows:

\section{Use of feeding materials during drought as adaptation strategy}

Lack of feed and fodder during the period of drought decrease in feed intake of livestock results into decrease in productivity of milch animals. Therefore, livestock dependents used to provide extra crop residues, extra concentrates to the livestock to maintaining productivity.

Table 1.0 explains majority of the livestock dependents from all three districts of nondrought prone (Gaya), moderately drought prone (Samastipur) and severely drought prone(Bhagalpur) adopted feeding extra concentrate ( $91.25 \%$, 98.75\% and $96.25 \%$, respectively) to the livestock. Maiti et al., (2014) reported that provision of extra concentrate to livestock feeding, providing minerals supplementation and feed additives, change in feeding schedule, change in grazing time. Excessive sweating in animals during hot and humid environment reduces body minerals like sodium and potassium level. Therefore, they provide common salt and mineral mixture to maintain the mineral quantity in animal's body. According to
Mallonee et al., (1985), lactating milch animal especially cows fed complete mixed diets with supplementation of potassium (K). Due to uneven distribution of monsoon paddy crop gets fail, under this situation majority of the livestock dependents (97.50\%) from severely drought prone districts used to feed immature paddy crop to their animals. Majority of the livestock dependents $(57.50 \%)$ of non-drought prone district used to graze their animals along roadside and in barren fields. Mineral supplementation and feed additives instead of green fodder were adopted by majority of livestock dependents of 91.25 percent, 100 percent and 98.75 percent from non-drought prone (Gaya), moderately drought prone (Samastipur) and severely drought prone (Bhagalpur) districts, respectively.

\section{Feeding practices followed during drought as adaptation strategy}

Table 1.1 explained that there were four adaptation strategies under the main headings of "feeding practices followed during drought". It was found that majority of livestock dependents (88.75\%) of severely drought prone district adopted adaptation strategy like 'limited/controlled feed/ fodder provide to the livestock' due to scarcity of fodder. Livestock dependents provided limited fodder to their livestock due to scarcity of feed and fodder during drought conditions. Sometimes they fed to animals only ensure to its survival or to maintain production at some extent to fulfill their family consumption. Adoption practices such as 'providing frequent extra clean and fresh feed/ water to the livestock to overcome heat stress' adopted by majority of livestock dependents $(98.75 \%, 100 \%$ and $97.5 \%$ of nondrought prone, moderately drought prone and severely drought prone district, respectively). Upadhyay et al., (2009); and Sirohi and Sirohi (2010) reported that the frequency of feeding 
should be increased and lower quantity of ration should be given during the day in order to improve the dry matter intake during summer and to reduce heat stress. Due to nonavailability of own fodder resources, livestock dependents purchased feed and fodder from outside to maintain the desired productivity of their animals. Most of the livestock dependents $(88.75 \%)$ of severely drought prone district were very sensitive to adopt the practices of 'feeding to animals only ensure to its survival or to maintain production at some extent and growth'. But, majority livestock dependents $(61.25 \%)$ of moderately drought prone district discontinued this practice.

\section{Strategies for meeting feed shortage in advance during drought as adaptation strategy}

Livestock dependents used to store wheat/paddy straw at the time when abundantly available so that it could be provided at the time of lean period. Storage by making hay was a common practice followed by livestock dependents. Maiti et al., (2014) reported that use of more quantity of crop residue and hay during heat stress period was an important adaptation strategy. Livestock dependents used to provide mixed ration of husk, maize, wheat, common salt and minerals at the time of shortage of fodder in order to enhance the productivity of animals. Table 1.2 clearly explains that almost every livestock dependents (100\%, $98.75 \%$ and $100 \%$ of non-drought prone, moderately drought prone and severely drought prone districts, respectively) adopted strategy against drought as 'storage of wheat straw/paddy straw and crop residues (like gram, mustard etc.) at the time when abundantly available'. Livestock dependents $(80.00 \%)$ of severely drought prone district adopted practices of storage by making hay and silage followed by the livestock dependents $(38.75 \%$ and $31.25 \%)$ of moderately drought and non- drought prone districts, respectively. Very few respondents adopted adaptation strategy such as 'preparation of total mixed ration. Majority of livestock dependents of severely drought prone district adopted the practice of 'storage of fodder by making hay and silage' followed by 'preparation of total mixed ration.

\section{Fodder production practices during drought as adaptation strategy}

Adaptation strategies like change in cropping intensity, change in cropping diversification, change in irrigation system/pattern (sprinkler/drip/pipe/others), altering sowing time/shift planting date of two or more crops, growing of high yielding fodder/crop varieties and growing high yielding perennial and multi-harvesting fodder varieties were the practices which adopted more by livestock dependents of severely drought prone district than the livestock dependents of others two districts. They used to grow drought tolerant crop like sorghum (Jowar), cluster bean (Guar), pearl millet (Bajra), maize (Makka) etc. as a fodder crop. The fodder tree as perennial crop like Subabul (Leucaena leucocephala) was common tree fodder grown at the time severe drought in the study area. Livestock dependents purposively used to cultivate early maturing variety of maize for fodder purposes under the stress condition. This local variety is 'Sathi', 'Jaunpur' etc. which used to mature in 70-80 days. Local Krishi Vigyan Kendra (Farm Science Centre) used to provide sorghum hybrid variety such as 'Pusa Chari Hybrid 109 (PCH 109)' to the livestock dependents as a contingent plan for fodder purpose in severely drought prone district. Table 1.3 found that almost all the livestock dependents (97.50 percent, 100 percent and 98.75 percent of non-drought prone, moderately drought prone and severely drought prone, respectively) adopted adaptation strategy 'change in cropping 
pattern'. Majority of the livestock dependents (76.25\%) of severely drought prone district adopted the practice like 'change in irrigation system/pattern' but in case of moderately drought prone district all the livestock dependents $(100 \%)$ adopted this practice and only 53.75 percent livestock dependents of non-drought prone district adopted this practices.

In Severely drought prone district, where 48.75 percent livestock dependents continued the adoption practices of 'water harvesting technology at the time of heavy rainfall' because they face the drought situation almost every year but 48.75 percent of the livestock dependents of moderately drought prone district never adopted this practice and only 7.50 percent continuing this practice.

\section{Practices followed for sustainable milk production during heat stress during drought as adaptation strategy}

Table 1.4 clearly indicates that livestock dependents of drought prone districts of Bihar was very much concerned regarding sustainable milk production of their animal across the different districts of varying degree of drought proneness. Therefore, they continued adoption of the six identified adaptation strategies like grazing of animal during early and cool hours, feeding and milking during cool hours, arrangement of shadow, extra bathing, extra concentrate and extra green fodder.

But, the livestock dependents of the nondrought prone and moderately drought prone district were having lower percentage to the adaptation strategy like feeding of animal during night hours. Upadhyay et al., (2009) reported that animals should be fed during morning hour because heat in the middle of the day would at peak due to high temperature. Livestock dependents, who depended on grazing grounds, altered grazing time of their animals from day time to early morning and evening during hot summer season to protect their animals from heat stress.

Maiti et al., (2014) reported that livestock rearers of coastal region took their animals to the grazing ground in the early morning and late afternoon. Livestock dependents of the study area perceived that feeding and milking during cool hours were beneficial in terms of productivity and health of animal(s). They perceived that body requires less water for digestion like in human during cool hours. Therefore, they used to feed their animal during night hours. They also kept their animal in shadow (either in shade or under the tree) place to prevent from excess water loss while sweating. Extra bathing of cattle and buffalo was also practiced by the livestock dependents to keep body temperature down.

\section{Modification in management practices as adaptation strategy}

Table 1.5 explains that livestock dependents of severely drought prone, moderately drought prone and non-drought prone district used to made shed outside the household by using locally available paddy straw on roof and side by side along with wet gunny bag which keep the internal temperature down. At the same time, few livestock dependents used fan during hot summer.

Hot summer (heat stress) affects the productivity of milk yield if the animals do not kept under favourable environment. Knapp and Grummer (1991) reported that either enhance convection by using fans or reduce air temperature by evaporating cooling or to directly cool the cow through using sprinklers and soakers are some of the strategies that may be followed to reduce heat stress. 
Livestock dependents mainly followed indigenous technical knowledge (ITK) to treat sick animal. The most effective way of combating heat stress in buffalo was wallowing in the water pond. Livestock dependents, who depended on grazing ground, avoid long distances during heat stress to protect their animals from sun stroke.

Few livestock dependents of severely drought prone district shifted their animal to the other bank of Ganga River for two months and used to come back when favourable conditions appear in the area. Majority of the livestock dependents from non-drought prone and severely drought prone districts interested in buffalo rather than cross breed.

\section{Other adaptation strategy}

They responded that buffaloes are more tolerable the stress condition than the crossbred and can be reared by inadequate fodder resources in comparison to cross breed. Cross breed also require higher care and management; ultimately livestock dependents faced loss economically.

Majority of the livestock dependents of severely drought prone district reduced their herd size by removing unproductive animals due to scarcity of feed and fodder resources. Table 1.5 also depicts that livestock dependents modified their management practices to cope up with drought.

Table.1 Use of feeding materials during drought as adaptation strategy adopted by livestock dependents of Gaya, Samastipur and Bhagalpur districts (Percentage)

\begin{tabular}{|c|c|c|c|c|c|c|c|c|c|c|}
\hline \multirow{2}{*}{\multicolumn{2}{|c|}{ Feeding materials }} & \multicolumn{3}{|c|}{$\begin{array}{l}\text { Non-drought Prone } \\
\quad(\text { Gaya; } \mathbf{n = 8 0})\end{array}$} & \multicolumn{3}{|c|}{$\begin{array}{l}\text { Moderately drought } \\
\text { Prone } \\
\text { (Samastipur; } \mathbf{n = 8 0} \text { ) }\end{array}$} & \multicolumn{3}{|c|}{$\begin{array}{l}\text { Severely drought } \\
\text { Prone } \\
\text { (Bhagalpur; } n=80 \text { ) }\end{array}$} \\
\hline & & $\mathbf{A C}$ & AD & $\mathbf{N A}$ & $\mathbf{A C}$ & AD & NA & $\mathbf{A C}$ & AD & $\mathbf{N A}$ \\
\hline i & $\begin{array}{l}\text { Feed extra concentrate } \\
\text { to the livestock }\end{array}$ & 91.25 & 3.75 & 5.00 & 98.75 & 1.25 & 0.00 & 96.25 & 0.00 & 3.75 \\
\hline ii & $\begin{array}{l}\text { Feeding of extra crop } \\
\text { residues }\end{array}$ & 100 & 0.00 & 0.00 & 100 & 0.00 & 0.00 & 100 & 0.00 & 0.00 \\
\hline iii & $\begin{array}{l}\text { Feeding immature } \\
\text { paddy crop which } \\
\text { unable to grown up due } \\
\text { to lack of water }\end{array}$ & 50.00 & 18.75 & 31.25 & 92.5 & 1.25 & 6.25 & 97.50 & 0.00 & 2.50 \\
\hline iv & $\begin{array}{l}\text { Feeding maize as } \\
\text { fodder to animals }\end{array}$ & 55.00 & 16.25 & 28.75 & 77.5 & 6.25 & 16.25 & 73.75 & 10.00 & 16.25 \\
\hline $\mathbf{v}$ & Feeding of tree leaves & 8.75 & 30.00 & 61.25 & 1.25 & 51.25 & 47.5 & 28.75 & 60.00 & 11.25 \\
\hline vi & $\begin{array}{l}\text { Grazing the animals } \\
\text { along road/canals }\end{array}$ & 57.50 & 41.25 & 1.25 & 36.25 & 63.75 & 0.00 & 50.00 & 50.00 & 0.00 \\
\hline vii & $\begin{array}{l}\text { Providing minerals and } \\
\text { feed additives instead } \\
\text { of green fodder }\end{array}$ & 91.25 & 2.50 & 6.25 & 100 & 0.00 & 0.00 & 98.75 & 1.25 & 0.00 \\
\hline
\end{tabular}

AC: Adoption Continued; AD: Adoption Discontinued; NA: Never Adopted 
Table.2 Feeding practices as adaptation strategy adopted by livestock dependents of Gaya, Samastipur and Bhagalpur district(Percentage)

\begin{tabular}{|c|c|c|c|c|c|c|c|c|c|c|}
\hline \multirow{2}{*}{\multicolumn{2}{|c|}{ Feeding practices }} & \multicolumn{3}{|c|}{$\begin{array}{l}\text { Non-drought Prone } \\
\text { (Gaya; } \mathbf{n = 8 0})\end{array}$} & \multicolumn{3}{|c|}{$\begin{array}{l}\text { Moderately drought } \\
\text { Prone (Samastipur; } \\
\text { n=80) }\end{array}$} & \multicolumn{3}{|c|}{$\begin{array}{l}\text { Severely drought } \\
\text { Prone (Bhagalpur; } \\
\text { n=80) }\end{array}$} \\
\hline & & $\mathbf{A C}$ & AD & NA & $\mathbf{A C}$ & AD & NA & $\mathbf{A C}$ & AD & NA \\
\hline $\mathbf{i}$ & $\begin{array}{l}\text { Limited/controlled } \\
\text { feed /fodder provide } \\
\text { to the livestock }\end{array}$ & 42.50 & 3.75 & 53.75 & 13.75 & 51.25 & 35.00 & 88.75 & 3.75 & 7.50 \\
\hline ii & $\begin{array}{l}\text { Feeding to animals } \\
\text { only ensure to its } \\
\text { survival or to } \\
\text { maintain production } \\
\text { at some extent and } \\
\text { growth }\end{array}$ & 40.00 & 5.00 & 55.00 & 12.50 & 61.25 & 26.25 & 88.75 & 3.75 & 35.00 \\
\hline iii & $\begin{array}{l}\text { To maintain desired } \\
\text { production by } \\
\text { purchasing feed and } \\
\text { fodder from out side }\end{array}$ & 61.25 & 10.00 & 28.75 & 90.00 & 7.50 & 2.50 & 85.00 & 3.75 & 7.50 \\
\hline iv & $\begin{array}{l}\text { Providing frequent } \\
\text { extra clean and fresh } \\
\text { feed/water to the } \\
\text { livestock to alleviate } \\
\text { heat stress }\end{array}$ & 98.75 & 1.25 & 0.00 & 100 & 0.00 & 0.00 & 97.50 & 2.50 & 0.00 \\
\hline
\end{tabular}

AC: Adoption Continued; AD: Adoption Discontinued; NA: Never Adopted

Table.3 Strategies for meeting feed shortage in advance as adaptation strategy adopted by livestock dependents of Gaya, Samastipur and Bhagalpur districts (Percentage)

\begin{tabular}{|c|c|c|c|c|c|c|c|c|c|c|}
\hline \multicolumn{2}{|c|}{$\begin{array}{l}\text { Strategies for meeting } \\
\text { feed shortage in } \\
\text { advance }\end{array}$} & \multicolumn{3}{|c|}{$\begin{array}{l}\text { Non-drought Prone } \\
\quad(\text { Gaya; } \mathbf{n = 8 0})\end{array}$} & \multicolumn{3}{|c|}{$\begin{array}{c}\text { Moderately drought } \\
\text { Prone (Samastipur } \\
\text {;n=80) }\end{array}$} & \multicolumn{3}{|c|}{$\begin{array}{l}\text { Severely drought } \\
\text { Prone (Bhagalpur; } \\
\text { n=80) }\end{array}$} \\
\hline I & $\begin{array}{l}\text { Storage of wheat } \\
\text { straw/paddy straw } \\
\text { and crop residues } \\
\text { (like gram, mustard } \\
\text { etc.) at the time } \\
\text { when abundantly } \\
\text { available }\end{array}$ & $\begin{array}{l}\mathbf{A C} \\
100\end{array}$ & $\begin{array}{l}\text { AD } \\
0.00\end{array}$ & $\begin{array}{l}\text { NA } \\
0.00\end{array}$ & $\begin{array}{c}\text { AC } \\
98.75\end{array}$ & AD & $\begin{array}{l}\text { NA } \\
0.00\end{array}$ & $\begin{array}{l}\mathbf{A C} \\
100\end{array}$ & $\begin{array}{l}\text { AD } \\
0.00\end{array}$ & $\begin{array}{c}\text { NA } \\
0.00\end{array}$ \\
\hline Ii & $\begin{array}{l}\text { Storage by making } \\
\text { hay and silage }\end{array}$ & 31.25 & 31.25 & 37.50 & 38.75 & 37.50 & 23.75 & 80.00 & 12.50 & 7.50 \\
\hline iii & $\begin{array}{l}\text { Preparation of total } \\
\text { mixed ration }\end{array}$ & 16.25 & 20.00 & 63.75 & 15.00 & 10.00 & 75.00 & 61.25 & 3.75 & 35.00 \\
\hline
\end{tabular}

AC: Adoption Continued; AD: Adoption Discontinued; NA: Never Adopted 
Table.4 Fodder production practices as adaptation strategy adopted by livestock dependents of Gaya, Samastipur and Bhagalpur districts (Percentage)

\begin{tabular}{|c|c|c|c|c|c|c|c|c|c|c|}
\hline \multirow{2}{*}{\multicolumn{2}{|c|}{ Fodder production practices }} & \multicolumn{3}{|c|}{$\begin{array}{l}\text { Non-drought Prone } \\
\quad(\text { Gaya; } n=80)\end{array}$} & \multicolumn{3}{|c|}{$\begin{array}{l}\text { Moderately drought } \\
\text { Prone (Samastipur } \\
\quad ; \mathbf{n = 8 0})\end{array}$} & \multicolumn{3}{|c|}{$\begin{array}{l}\text { Severely drought Prone } \\
\quad \text { (Bhagalpur; } n=80)\end{array}$} \\
\hline & & $\mathbf{A C}$ & AD & NA & $\mathbf{A C}$ & AD & NA & $\mathbf{A C}$ & AD & NA \\
\hline $\mathbf{i}$ & Change in cropping intensity & 97.50 & 2.50 & 0.00 & 100 & 0.00 & 0.00 & 98.75 & 1.25 & 0.00 \\
\hline ii & Change in cropping diversification & 92.50 & 6.25 & 1.25 & 100 & 0.00 & 0.00 & 100 & 0.00 & 0.00 \\
\hline iii & $\begin{array}{l}\text { Change in irrigation } \\
\text { system(sprinkler/drip/others) }\end{array}$ & 53.75 & 10.00 & 36.25 & 100 & 0.00 & 0.00 & 76.25 & 1.25 & 22.50 \\
\hline iv & $\begin{array}{l}\text { Use water harvesting technology at the time of } \\
\text { heavy rainfall to avail livestock and agriculture } \\
\text { when there is the scarcity of water during } \\
\text { drought }\end{array}$ & 1.25 & 16.25 & 82.50 & 7.50 & 43.75 & 48.75 & 48.75 & 11.25 & 40.00 \\
\hline $\mathbf{v}$ & Use of drought resistant/tolerant crop varieties & 8.75 & 10.00 & 81.25 & 3.75 & 20.00 & 76.25 & 53.75 & 11.25 & 35.00 \\
\hline vi & $\begin{array}{l}\text { Altering sowing time/ shift planting date of two } \\
\text { or more crops }\end{array}$ & 73.75 & 0.00 & 26.25 & 97.50 & 1.25 & 1.25 & 85.00 & 1.25 & 13.75 \\
\hline vii & Use short duration or early maturing varieties & 53.75 & 3.75 & 42.50 & 72.50 & 6.25 & 21.25 & 80.00 & 6.25 & 13.75 \\
\hline $\begin{array}{l}\text { vii } \\
\text { i }\end{array}$ & $\begin{array}{l}\text { Growing high yielding perennial and multi- } \\
\text { harvesting fodder varieties }\end{array}$ & 68.75 & 7.50 & 23.75 & 77.50 & 7.50 & 15.00 & 77.50 & 5.00 & 17.50 \\
\hline ix & Growing of high yielding fodder/crop varieties & 78.75 & 5.00 & 16.25 & 92.50 & 5.00 & 2.50 & 77.50 & 5.00 & 17.50 \\
\hline $\mathbf{x}$ & Growing of fodder trees & 0.00 & 3.75 & 96.25 & 2.50 & 3.75 & 93.75 & 22.50 & 15.00 & 62.50 \\
\hline $\mathbf{x i}$ & Integrated fodder production system & 2.50 & 1.25 & 96.25 & 6.25 & 3.75 & 90.00 & 31.25 & 3.75 & 65.00 \\
\hline
\end{tabular}


Table.5 Practices followed for sustainable milk production during heat stress as adaptation strategy adopted by livestock dependents of Gaya, Samastipur and

Bhagalpur districts (Percentage)

\begin{tabular}{|c|c|c|c|c|c|c|c|c|c|c|}
\hline \multirow{2}{*}{\multicolumn{2}{|c|}{$\begin{array}{c}\text { Practices followed for sustainable milk production } \\
\text { during heat stress }\end{array}$}} & \multicolumn{3}{|c|}{$\begin{array}{l}\text { Non-drought Prone } \\
\quad(\text { Gaya; } n=80)\end{array}$} & \multicolumn{3}{|c|}{$\begin{array}{l}\text { Moderately drought } \\
\text { Prone (Samastipur } \\
\text {;n=80) }\end{array}$} & \multicolumn{3}{|c|}{$\begin{array}{c}\text { Severely drought } \\
\text { Prone (Bhagalpur; } \\
\text { n=80) }\end{array}$} \\
\hline & & $\mathbf{A C}$ & AD & NA & $\mathbf{A C}$ & AD & NA & $\mathbf{A C}$ & AD & NA \\
\hline $\mathbf{i}$ & Grazing during early morning and evening & 98.75 & 1.25 & 0.00 & 100 & 0.00 & 0.00 & 93.75 & 6.25 & 0.00 \\
\hline ii & Feeding and milking during cool hours & 100 & 0.00 & 0.00 & 100 & 0.00 & 0.00 & 100 & 0.00 & 0.00 \\
\hline iii & $\begin{array}{l}\text { Kept the animals in shadow place to maintain thirst } \\
\text { up to some extent in drought }\end{array}$ & 100 & 0.00 & 0.00 & 100 & 0.00 & 0.00 & 98.75 & 1.25 & 0.00 \\
\hline iv & $\begin{array}{l}\text { Extra bathing of cattle and buffaloes (2-3 times a } \\
\text { day) }\end{array}$ & 90.00 & 5.00 & 5.00 & 100 & 0.00 & 0.00 & 98.75 & 1.25 & 0.00 \\
\hline $\mathbf{v}$ & $\begin{array}{l}\text { Feeding extra concentrate mixture to overcome } \\
\text { heat stress }\end{array}$ & 96.25 & 1.25 & 2.50 & 100 & 0.00 & 0.00 & 97.50 & 1.25 & 1.25 \\
\hline vi & Feeding more green fodder during heat stress & 91.25 & 3.75 & 5.00 & 100 & 0.00 & 0.00 & 88.75 & 1.25 & 10.00 \\
\hline vii & Feeding during night hours & 17.50 & 0.00 & 82.50 & 13.75 & 3.75 & 82.50 & 66.25 & 12.5 & 21.25 \\
\hline
\end{tabular}

AC: Adoption Continued; AD: Adoption Discontinued; NA: Never Adopted 
Table.6 Modification in management practices as adaptation strategy adopted by livestock dependents of Gaya, Samastipur and Bhagalpur districts (Percentage)

\begin{tabular}{|c|c|c|c|c|c|c|c|c|c|c|}
\hline \multirow{2}{*}{\multicolumn{2}{|c|}{ Modification in management practices }} & \multicolumn{3}{|c|}{$\begin{array}{l}\text { Non-drought Prone } \\
\quad(\text { Gaya;n=80) }\end{array}$} & \multicolumn{3}{|c|}{$\begin{array}{l}\text { Moderately drought } \\
\text { Prone (Samastipur; } \\
\qquad \mathbf{n = 8 0} \text { ) }\end{array}$} & \multicolumn{3}{|c|}{$\begin{array}{l}\text { Severely drought Prone } \\
\quad \text { (Bhagalpur; } n=80)\end{array}$} \\
\hline & & $\mathbf{A C}$ & AD & NA & $\mathbf{A C}$ & AD & NA & $\mathbf{A C}$ & AD & NA \\
\hline i & $\begin{array}{l}\text { Making of shed outside the household by using } \\
\text { locally available resources }\end{array}$ & 76.25 & 15.00 & 8.75 & 93.75 & 2.50 & 3.75 & 86.25 & 6.25 & 7.50 \\
\hline ii & $\begin{array}{l}\text { Farmer is used mosquito net for their family and } \\
\text { smoke (fumigation of cow-dung cake) for their } \\
\text { animals }\end{array}$ & 98.75 & 1.25 & 0.00 & 100 & 0.00 & 0.00 & 100 & 0.00 & 0.00 \\
\hline iii & $\begin{array}{l}\text { Changing of microclimate of the cattle shed by } \\
\text { sprinkler/fan }\end{array}$ & 58.75 & 0.00 & 41.25 & 92.50 & 0.00 & 7.50 & 87.50 & 0.00 & 12.50 \\
\hline iv & $\begin{array}{l}\text { Use of ITKs to treat the sick animal due to heat } \\
\text { stress }\end{array}$ & 78.75 & 21.25 & 0.00 & 95.00 & 5.00 & 0.00 & 78.75 & 21.25 & 0.00 \\
\hline $\mathbf{v}$ & $\begin{array}{l}\text { To avoid long distance grazing at the time of heat } \\
\text { stress }\end{array}$ & 91.25 & 0.00 & 8.75 & 98.75 & 1.25 & 0.00 & 88.75 & 0.00 & 10.00 \\
\hline vi & Shifting to small ruminant from large ruminant & 40.00 & 51.25 & 8.75 & 11.25 & 88.75 & 0.00 & 50.00 & 50.00 & 0.00 \\
\hline vii & Shifting to another place along with animals & 13.75 & 6.25 & 80.00 & 1.25 & 0.00 & 98.75 & 21.25 & 63.75 & 15.00 \\
\hline viii & $\begin{array}{l}\text { Farmers keep their animals their friends or } \\
\text { relatives(having availability of fodder) during } \\
\text { lean period }\end{array}$ & 12.50 & 7.50 & 80.00 & 1.25 & 5.00 & 93.75 & 17.50 & 56.25 & 26.25 \\
\hline ix & $\begin{array}{l}\text { Keeping/promoting/interested in local breed } \\
\text { instead of exotic breed }\end{array}$ & 51.25 & 48.75 & 0.00 & 18.75 & 81.25 & 0.00 & 31.25 & 68.75 & 0.00 \\
\hline $\mathbf{x}$ & Reduction in herd size & 67.50 & 25.00 & 7.50 & 65.00 & 35.00 & 0.00 & 96.25 & 0.00 & 2.50 \\
\hline $\mathbf{x i}$ & Selling of few animals from the stock or assets & 77.50 & 21.25 & 1.25 & 58.75 & 41.25 & 0.00 & 97.50 & 1.25 & 0.00 \\
\hline
\end{tabular}

AC: Adoption Continued; AD: Adoption Discontinued; NA: Never Adopted 
Table.7 Other adaptation strategy adopted by livestock dependents of Gaya, Samastipur and Bhagalpur districts (Percentage)

\begin{tabular}{|c|c|c|c|c|c|c|c|c|c|c|}
\hline \multirow{2}{*}{\multicolumn{2}{|c|}{$\begin{array}{l}\text { Drought Adaptation } \\
\text { strategy }\end{array}$}} & \multicolumn{3}{|c|}{$\begin{array}{l}\text { Non-drought Prone } \\
\quad(\text { Gaya; } n=80)\end{array}$} & \multicolumn{3}{|c|}{$\begin{array}{l}\text { Moderately drought } \\
\text { Prone (Samastipur; } \\
\qquad \mathbf{n = 8 0})\end{array}$} & \multicolumn{3}{|c|}{$\begin{array}{c}\text { Severely drought } \\
\text { Prone (Bhagalpur; } \\
\text { n=80) }\end{array}$} \\
\hline & & $\mathbf{A C}$ & AD & NA & $\mathbf{A C}$ & AD & NA & $\mathbf{A C}$ & AD & NA \\
\hline i & $\begin{array}{l}\text { Livestock } \\
\text { insurance }\end{array}$ & 1.25 & 0.00 & 98.75 & 0.00 & 1.25 & 98.75 & 5.00 & 0.00 & 95.00 \\
\hline ii & $\begin{array}{l}\text { Selling of animal } \\
\text { for fulfill } \\
\text { household } \\
\text { requirement }\end{array}$ & 96.25 & 1.25 & 2.50 & 100 & 0.00 & 0.00 & 98.75 & 0.00 & 1.25 \\
\hline iii & $\begin{array}{l}\text { Selling of land to } \\
\text { meet household } \\
\text { requirement }\end{array}$ & 73.75 & 20.00 & 6.25 & 73.75 & 26.25 & 0.00 & 86.25 & 10.00 & 3.75 \\
\hline iv & Social Migration & 33.75 & 55.00 & 11.25 & 28.75 & 68.75 & 2.50 & 66.25 & 28.75 & 5.00 \\
\hline $\mathbf{v}$ & $\begin{array}{l}\text { Search of alternate } \\
\text { sources of income }\end{array}$ & 81.25 & 16.25 & 2.50 & 51.25 & 46.25 & 2.50 & 95.00 & 3.75 & 1.25 \\
\hline vi & Loan from bank & 13.75 & 3.75 & 82.50 & 28.75 & 1.25 & 70.00 & 15.00 & 5.00 & 80.00 \\
\hline
\end{tabular}

AC: Adoption Continued; AD: Adoption Discontinued; NA: Never Adopted

Adaptation strategy like 'used of mosquito net for the family and smoke (fumigation of cow dung or wood) for the animals' was adopted by the almost every livestock dependents and continued this adoption across the districts having varying degree of drought proneness. Table 1.6 explained that majority of livestock dependents used to sell their animals in miserable condition to fulfil the requirement of their family. Along with this if any big issue in the family like fatal diseases, marriages etc they often used to sell land to meet their requirements.

Majority of the livestock dependents of severely drought prone district migrated to the city for job. It was very difficult to take crop loan for the livestock dependents. Therefore, livestock insurance was very poorly adopted. Table 1.6 clearly depicts that selling of animal for fulfil household requirement was the first preference among the all most all the livestock dependents of each districts of non-drought prone, moderately drought prone and severely drought prone. Search for an alternate source of income, migrate to the city and selling of land were getting higher preferences among the livestock dependents of drought prone districts of Bihar. But, due to poor level of awareness, they did not prefer livestock insurance. It was also found that acceptability of the intuitional credit was very low among the livestock dependents of drought prone districts.

\section{Acknowledgement}

We have a sincere gratitude to the Director, ICAR-National Dairy Research Institute, Karnal for providing all the facilities for this study. We are also thankful to our esteemed 
livestock dependents for sharing their views and giving time for the research work.

\section{References}

Anonymous. 2014. Memorandum to the central government seeking assistance for combating drought in Bihar 2013.Department of Disaster management, Govt. of Bihar.

Adger, W.N. 1999. Social vulnerability to climate change and extremes in Coastal Vietnam. World Development, 27 (2): 249-269.

Adger, W.N. 2000. Institutional adaptation to environmental risk under transition in Vietnam. Annals of the Association of American Geographers, 90 (4): 738-758.

Kane, S.M. and Shogren, J. F. 2000. Linking adaptation and mitigation in climate change policy. Climatic Change, 45 (1): 75-102.

Knapp, D.M. and Grummer, R.R. 1991. Response of lactating dairy cows to fat supplementation during heat stress.J. Dairy Science, 74: 2573-2579.

Maiti S, Jha S K, Garai S, Nag A, Chakravarty R, Kadian K S,Chandel B S, Datta K K and Upadhaya R C. 2014a. Adaptation strategies followed by the livestock rearers of coastal Odisha and West Bengal to cope up with climate change. Indian Journal of Animal Sciences 84 (6): 652-59.

Maiti, S.,Jha, S. K., Garai, S., Nag, A., Chakravarty, R., Kadian, K.S., Chandel, B. S., Datta, K. K. and Upadhaya, R.C. 2014. Adaptation Strategies followed by the Livestock Rearers of Coastal Odisha and West Bengal to Cope up with Climate Change.Indian Journal of Animal sciences, 84 (6): 652-659.

Mallone, P. G., Beede, D. K., Collier, R. J. and Wilcox, C. J. 1985. Production and psychological response of dairy cows to varying dietary potassium during heat stress. Journal of Dairy Science, 68:1479.

Patt, A.G. and Gwata, C., 2002. Effective seasonal climate forecast applications: examining constraints for subsistence farmers in Zimbabwe. Global Environmental Change. 12: 185-195.

Pielke, R.A. 1998. Rethinking the role of adaptation in climate policy. Global Environmental Change, 8 (2): 159170.

Ribot, J. C., Magalhães, A. R., and Panagides, S. S. (eds.). 1996. Climate Variability, Climate Change and Social Vulnerability in the Semi-Arid Tropics, Cambridge University Press, Cambridge.

Ribot, J. 2002. Democratic Decentralization of Natural Resources: Institutionalizing Popular Participation. World Resources Institute, Washington, DC.

Sirohi, S. and Sirohi, S. 2010. Vulnerability of milk producers to climate change: technological and policy options for livelihood security. Published in the compendium of National Symposium on Climate Change and Livestock Productivity in India at NDRI, Karnal during October 7-8, 2010.

Smit, B., Burton, I., Klein R. J. T. and Wandel, J. 2000. An anatomy of adaptation to climate change and variability.Climate Change, 45(1): 223-251.

Smit, B. and Pilifosova, O. 2001.Adaptation to climate change in the context of sustainable development and equity. In: McCar thy, J.J., Canziani, O.F., Leary, N.A., Dokken,D.J., White, K.S. (Eds.), Climate Change 2001:Impacts, Adaptation and Vulnerability. Cambridge University Press, Cambridge, pp. 877-912. 
Smit, B. and Wandel, J. 2006. Adaptation, adaptive capacity and vulnerability.Global Environmental Change Human Policy Dimensions, 16: 282.

Upadhyay, R.C., Ashutosh, Raina, V.S. and
Singh S.V. 2009. Impact of climate change on reproduction functions of cattle and buffaloes. In: Global climate change and Indian Agriculture, P.K. Aggarwal (Editor), ICAR, New Delhi, 107-110.

\section{How to cite this article:}

Randhir Kumar Goswami, Sanjit Maiti, Sanchita Garai, S. K. Jha, M. Bhakat, B. S. Chandel and Kadian. K. S. 2020. Degree of Adaptation Strategies by the Livestock Dependents of Drought Prone Districts of Bihar, India. Int.J.Curr.Microbiol.App.Sci. 9(03): 1082-1094.

doi: https://doi.org/10.20546/ijcmas.2020.903.127 